\title{
Sobre rejeições de trabalhos encaminhados à publicação
}

\author{
Harley E. A. Bicas
}

Entre as atividades editoriais, certamente a mais desconfortável é a de rejeitar um artigo enviado para publicação. De fato, não é agradável a qualquer pessoa normal dizer a outras que o trabalho por elas concluído, consumindo tempo e energias, traduzindo expectativas e aspirações, não está em condições de aceitação. Na verdade, há todo um cuidado no exame das condições de recusa. Embora a responsabilidade final caiba à chefia editorial, ela geralmente é nisso guiada por opiniões de conselheiros designados para exame minucioso das matérias enviadas à publicação e do editor associado incumbido do processo de suas análises. Claro que quaisquer dessas pessoas, ou todas, podem se enganar e injustiças serem consumadas. Mas os riscos têm que ser assim assumidos.

Vários aspectos emolduram, aí, essa delicada circunstância. Em primeiro lugar, afastemos a hipótese, ainda que provável, de uma decisão dolosa, a de rejeição do trabalho por um conflito de interesses entre aquilo que ele postula e os do seu analista. Conflitos de interesses podem assumir formas variadas, tanto a de um trabalho cuja apresentação antecipa conteúdos (objetivações, métodos, resultados ou conclusões) dos de outro de autoria de quem o examina, ou de seu grupo, quanto a de contradizer e contrariar procedimentos e crenças desse mesmo juiz. Trata-se sobretudo de um problema ético, em que uma conduta consciente, mas pervertida do julgador busca auferir vantagens, negando a publicação do trabalho de outras pessoas ou grupos. Sabe-se que ele é bom, merece divulgação, mas se quer evitá-la por egoísmos, invejas, ciúmes científicos, sentimentos incompatíveis com a evolução do saber e a imparcialidade de sua avaliação. Essas práticas são costumeiramente coibidas pela vigilância indireta dos grupamentos científicos e por cuidados editoriais sobre o assunto. $\mathrm{O}$ simples fato de a análise não ser atribuída a uma única pessoa reduz consideravelmente esse tipo de recusa. Além disso, os próprios consultores são previamente instados a se omitir da análise a eles requerida, se tiverem interesses sobre o assunto que possam interferir com a necessária isenção do julgamento.

Depois, vem a possibilidade do erro ainda consciente, mas agora revestido pela intenção de impedir aquilo que se julga um mau exemplo, a abertura de caminhos impróprios. Esse é um tipo de censura "preventiva", cuja aplicação gera interpretações discutíveis e, ou posturas dúbias: aceita-se a condenação ao uso da energia nuclear para fins destrutivos (a não ser para a necessária pulverização de um asteróide que se aproximasse da Terra, em rota de colisão), mas não se aceita que se houvesse condenado o heliocentrismo de Copérnico (conhecimento igualmente achado perigoso para a sociedade humana da época e perturbador de equilíbrios institucionais). O que hoje não é bom, pode ser bom amanhã e vice-versa. Em Oftalmologia, não são poucas as questões, ainda recentes, que suscitaram e suscitam dúvidas. $\mathrm{O}$ exame desses aspectos requer, entretanto, atenção especial, não devendo ser agora, aqui, tratado.

Há a possibilidade de erro em si mesmo, a da avaliação equivocada do juiz que, imbuído de convicções fundadas em seus conhecimentos (que nunca, entretanto, são completos) e achando acertar em nome da ciência, profere uma sentença injusta. Esse, talvez, seja o tipo mais doloroso de erro (não o mais grave) mas, também, o de reparação geralmente concedida ao injustiçado, com execração dos que se contrapuseram à sua idéia. São inúmeros os casos na história da ciência em que conhecimentos, hoje tomados como indiscutíveis, foram ridicularizados quando inicialmente propostos. Nesse caso, há um erro de boa-fé.

Todas essas formas de recusa podem ser tomadas como “estruturais", cabíveis como um capítulo da Epistemologia, de como se dá o julgamento do avanço científico pelos detentores do conhecimento, os considerados "pares". Mas felizmente para os editores, são as menos comuns. Ao contrário, as recusas "funcionais", isto é, as que se dão por razões técnicas são as mais freqüentes nas redações das revistas científicas.

Uma delas é a da pertinência do trabalho. Como cada revista tem uma "especialização", um perfil, não se espera que uma de Oftalmologia publique um artigo sobre a teoria quântica, ainda que ele possa futuramente vir a ser agraciado com o prêmio Nobel (de Física). O valor intrínseco de um artigo não é, pois, a única condição de sua aprovação para publicação.

Outra é a da originalidade. Muitas vezes, o trabalho já apresenta uma falha em sua concepção, na objetivação pela qual ele é realizado. Alguns se fecham sobre si próprios, chegando a conclusões tautológicas. Por exemplo, a de que complicações num tipo de cirurgia diminuem com os cuidados tomados e com o tempo de experiência adquirida pelo cirurgião. Outros são meramente casuísticos, relatando a prevalência de uma determinada afecção numa cidade ou região; ou "mais um caso" de certa síndrome; ou "meus (ou nossos) resultados com a aplicação da técnica X”. Em quaisquer desses casos, ou de outros, similares, falta o propósito inicial de preencher uma lacuna do conhecimento, resolver uma controvérsia encontrada na literatura, melhorar (em tempo, custo, resultados) a aplicação de uma técnica (diagnóstica ou terapêutica), enfim, prover uma informação com a qual se beneficie o exercício prático da especialidade, ou se investigue uma proposta que possa vir a antecipá-lo, avançá-lo. Geralmente, pela leitura da Introdução já se pode perceber a que vem (ou não) o artigo, embora apenas isso não seja sempre suficiente.

É claro que o primeiro levantamento sobre a prevalência de ambliopia numa determinada cidade, quando isso ainda nunca 
fora feito, pode ser interessante por constatar que sua população também se enquadra nos padrões mundiais (ou, pelo menos, nacionais) já divulgados sobre o assunto. Mas essa reverberação não preenche os critérios de novidade, um importante indicador de "originalidade". Ao contrário, o achado de um índice significativamente díspar do que se tem por norma, merece atenção. Claro que aí entram as análises para determinar se tais índices são, ou não, resultantes de um método enviesado (o que, igualmente, determinaria a recusa à publicação do artigo, mas agora por razões de método, não de resultado ou proposta).

Portanto, outro fator potencialmente gerador da rejeição de trabalhos é o do método como ele foi desenvolvido. Nesse aspecto, há campo para controvérsias, mas às vezes o desenho de aquisição de informações no estudo já se mostra tão francamente inadequado que apenas essa condição já será determinante da rejeição antecipada do trabalho. Lembre-se que um critério oportuno para uma investigação pode não sê-lo para outra. Por exemplo: "respostas à pergunta sobre qualidade da visão" são inadequadas como critério de avaliação dessa função numa população, pelo subjetivismo nele contido. Mas fundamentais, se o que se pretende avaliar é, justamente, a opinião do usuário sobre tal questão, num certo contexto.
Dentro do método, insere-se o requisito da quantidade dos casos. Um bom método, mas com um pequeno número de observações, talvez cabente como "nota prévia", pode ser recusado como artigo "acabado", por insuficiência demonstrativa. Obviamente, não é a transpiração dos autores, a quantidade de esforços despendidos num trabalho, o que o torna merecedor de publicação, mas ingrediente também importante em seu exame.

Curiosamente, pertinência e originalidade do assunto, mais método de realização de estudo (adequação e quantidades) representam importantes fatores de rejeição inicial de trabalhos. Resultados e como são analisados ou discutidos, para levar a conclusões, são necessariamente importantes, mas os aspectos a eles subordinados costumam fazer parte das - por vezes longas - mediações editoriais (na sigilosa interlocução de revisores e autores).

Finalmente, discrepâncias podem ocorrer e um artigo relativamente impertinente (alguns acham que certos procedimentos experimentais realizados em animais deveriam ser publicados em revistas de veterinária; outros não), ou com baixa originalidade ou, talvez, com pequena casuística (mas a descrição de um caso de sucesso no tratamento da raiva não seria digno de publicação?) podem aparecer. Editores também erram. Não só por rejeições como, também, por aceitações... 